\title{
Meningkatkan Kinerja Keuangan dan Nilai Perusahaan Dalam Berinvestasi
}

\author{
Yudhistira Ardana \\ STMIK Pringsewu Lampung \\ Jalan Wismarini No. 09 Pringsewu, Telpon (0729) 22240 kode pos 35373, \\ Kabupaten Pringsewu, Lampung, Indonesia \\ email: ardanayudhistira@gmail.com
}

\begin{tabular}{c}
\hline Artikel Info \\
\hline Received: \\
22 Juli 2018 \\
Revised: \\
13 Agustus 2018 \\
Accepted: \\
12 September 2018
\end{tabular}

\begin{abstract}
ABSTRAK
Penelitian ini bertujuan untuk mengetahui pengaruh kinerja keuangan terhadap nilai perusahaan. Pengambilan data dilakukan pada tahun 2012 sampai dengan tahun 2017. Penelitian ini menganalisis pengaruh kinerja keuangan yang diproksikan dengan 3 (tiga) variabel bebas, yaitu rasio likuiditas (quick ratio), rasio profitabilitas (ROA), dan rasio solvabilitas (Debt to Total Assets Ratio) terhadap nilai perusahaan (Price Book Value) pada perusahaaan yang terdaftar di Jakarta Islamic Index (JII). Teknik analisis data yang digunakan dalam penelitian ini adalah menggunakan regresi data panel. Hasil penelitian ini yaitu variabel independen rasio profitabilitas dan solvabilitas berpengaruh secara positif dan signifikan terhadap variabel dependen berupa nilai perusahaan yang diukur dengan Price to Book Value (PBV). Sedangkan variabel independen rasio likuiditas yang diukur dengan quick ratio tidak memiliki pengaruh terhadap nilai perusahaan.
\end{abstract}

Kata Kunci: Kinerja keuangan, Profitabilitas, Likuiditas, Solvabilitas

\section{Improving Financial Performance and Corporate Value in Investing}

\begin{abstract}
This study aims to determine the effect of financial performance on firm value. Data collection was carried out from 2012 until 2017. This study analyzed the effect of financial performance which is proxied by 3 (three) independent variables, namely quick ratio, Return on Assets (ROA), Debt to Total Assets Ratio to Price Book Value $(P B V)$ for companies listed in the Jakarta Islamic Index (JII). The data analysis technique used in this study is using panel data regression. The results of this study are independent variables profitability and solvency ratios have a positive and significant effect on the dependent variable in the form of firm value as measured by Price to Book Value $(P B V)$. While the independent variable liquidity ratio measured by the quick ratio has no influence on the value of the company.
\end{abstract}

Keywords: Financial performance, profitability, liquidity, solvency

Cara Sitasi :

Ardana, Y. (2018). Meningkatkan Kinerja Keuangan dan Nilai Perusahaan Dalam Berinvestasi. Jurnal Ilmiah Manajemen dan Bisnis, 19(2),89-96. https://doi.org/10.30596/jimb.v19i2.2020. 


\section{PENDAHULUAN}

Perusahaan di Indonesia umumnya dituntut untuk selalu mempertahankan keunggulan bisnisnya di tengah persaingan bisnis yang semakin ketat. Berdirinya sebuah perusahaan memiliki tujuan utama yaitu untuk memaksimumkan kesejahteraan atau kekayaan para pemegang saham, yang mana dapat diartikan dengan memaksimumkan harga saham guna meningkatkan nilai perusahaan tersebut (Febrianti, 2012). Perusahaan merupakan penyatuan antara berbagai kepentingan pemegang saham (shareholders) dan manajemen yang bertujuan memaksimalkan nilai perusahaan. Itu berarti memaksimalkan nilai kekayaan para pemegang saham adalah tujuan akhir dari suatu perusahaan. Peningkatan nilai perusahaan mengindikasikan meningkatnya kekayaan pemegang saham (Mangantar \& Ali, 2015).

Putu, et al, (2014) memberikan penjelasan bahwa nilai perusahaan merupakan persepsi investor terhadap perusahaan yang sering dikaitkan dengan harga saham. Bagi perusahaan publik nilai perusahaan yang biasanya dicerminkan oleh harga pasar (market price) saham perusahaan tersebut. Para investor membeli saham biasa karena mereka mengharapkan suatu imbalan (return) atas investasi mereka. Imbalan ini dapat berupa apresiasi harga saham dan deviden kepada para pemegang saham (Simamora, 2010). Nilai perusahaan dapat dilihat dari harga penjualan sahamnya, karena para investor dapat menilai perusahaan tersebut memiliki keuntungan yang tinggi atau tidak dari tingginya harga saham.

Pada dasarnya harga saham dipengaruhi oleh profitabilitas di masa yang akan datang dan risiko yang ditanggung oleh pemodal. Harga saham yang tinggi membuat nilai perusahaan juga tinggi. Nilai perusahaan yang tinggi akan membuat pasar tidak hanya percaya pada kinerja perusahaan saat ini namun juga pada prospek masa depan perusahaan (Mangantar \& Ali, 2015). Untuk menilai suatu perusahaan dari harga pasar saham, biasanya digunakan pengukuran kinerja perusahaan. Semakin baik kinerja perusahaan, maka semakin tinggi return yang akan diperoleh oleh investor (Meythi, 2013). Bagi perusahaan, menjaga dan meningkatkan kinerja perusahaan adalah suatu keharusan agar saham perusahaan tersebut tetap eksis dan tetap diminati oleh para investor $(\mathrm{Dj}$, et al., 2012).

Untuk mengukur kinerja keuangan suatu perusahaan dapat dilakukan dengan menganalisis laporan keuangan pada perusahaan tersebut, salah satu caranya adalah dengan melakukan analisis rasio keuangan perusahaan, karena analisis laporan keuangan yang banyak digunakan adalah rasio keuangan (Santoso, 2016). Rasio keuangan berguna dalam mengidentifikasi variabel keuangan utama dan hubungan antara variabel dengan maksud memberi makna pada berbagai hubungan sambil memastikan kekuatan dan kelemahan dari sebuah perusahaan. Dalam penelitian ini kinerja suatu perusahaan diukur dengan rasio-rasio keuangan. Rasiorasio keuangan tersebut adalah likuiditas yang diukur dengan Quick Ratio, solvabilitas yang diukur dengan Debt to Total Asset serta profitabilitas yang diukur dengan Return on Assets. Sedangkan nilai perusahaan diukur dengan Price Book Value

Hubungan antara ketiga rasio di atas sebagai alat pengukur kinerja perusahaan dengan nilai perusahaan, penelitian yang dilakukan oleh Wang, (2002) menyatakan bahwa manajemen likuiditas berpengaruh negatif signifikan terhadap nilai perusahaan yang terdapat di Negara Jepang dan Taiwan. Sementara hasil penelitian Cheung, et al., (2015) menyatakan bahwa terdapat pengaruh yang positif dan signfikan antara likuiditas saham REIT (Real Estate 
Investment Trust) dengan nilai perusahaan. Hasil penelitian tersebut ini di dukung oleh penelitian Fang, et al., (2009) yang menyatakan bahwa terdapat pengaruh signifikan antara likuiditas dengan nilai perusahaan. Penelitian Sidhu, (2012) juga menyatakan bahwa likuiditas pasar saham berpengaruh signifikan terhadap nilai perusahaan di Negara India. Aggarwal \& Padhan, (2017) menyatakan bahwa likuiditas berpengaruh terhadap nilai perusahaan. Berbeda halnya dengan hasil penelitian Firnanda \& Oetomo, (2016) dimana likuiditas tidak berpengaruh secara signifikan terhadap nilai perusahaan pada perusahaan retail home yang terdaftar di Bursa Efek Indonesia. Hasil penelitian Dj et al., (2012) juga menyatakan bahwa kinerja keuangan dengan proksi likuiditas berpengaruh positif tidak signifikan terhadap nilai perusahaan pada perusahaan manufaktur di Bursa Efek Indonesia. Sementara itu hasil penelitian (Febrianti, 2012) juga menyatakan bahwa likuiditas tidak memiliki pengaruh signifikan terhadap nilai perusahaan pertambangan di Indonesia.

Selanjutnya, hubungan antara rasio profitabilitas dengan nilai perusahaan, menurut penelitian yang dilakukan oleh Sucuahi \& Cambarihan, (2016); Sabrin, et al., (2016); Andawasatya, et al.,(2017) menyatakan bahwa profitabilitas berpengaruh signifikan terhadap nilai perusahaan pada perusahaan yang terdapat di negara Filipina. Sedangkan penelitian Porwohandoko (2017) menyatakan bahwa profitabilitas berpengaruh negatif dan signifikan terhadap nilai perusahaan pertanian yang terdaftar di Bursa Efek Indonesia. Berbeda dengan hasil penelitian sebelumnya, Aggarwal \& Padhan, (2017) menyatakan bahwa profitabilitas tidak berpengaruh terhadap nilai perusahaan.

Kemudian hubungan antara rasio solvabilitas dengan nilai perusahaan, menurut penelitian yang dilakukan oleh Santoso (2016); Firnanda \& Oetomo, (2016) menunjukkan hasil yang menyatakan bahwa rasio solvabilitas berpengaruh secara signifikan terhadap nilai perusahaan. Hal ini diperkuat oleh penelitian yang dilakukan oleh Susilaningrum, (2016) yang menyatakan bahwa terdapat pengaruh rasio solvabilitas terhadap nilai perusahaan pada industri sektor pertambangan pada periode 2012-2014, kemduian penelitian Sianturi, (2015) diperoleh hasil yang menyatakan bahwa solvabilitas berpengaruh negatif signifikan terhadap nilai perusahaan pada sektor industri barang konsumsi di Bursa Efek Indonesia, demikian juga dengan temuan Prajanto \& Pratiwi, (2017); (Erlina, 2018) menyatakan bahwa solvabilitas tidak berpengaruh terhadap nilai perusahaan pada perusahaan manufaktur dan sektor pertambangan yang terdaftar di Bursa Efek Indonesia.

Secara substansi penelitian sahamsaham yang terdaftar pada Jakarta Islamic Index, karena mayoritas penduduk Indonesia beragama Islam dan belakangan ini sudah banyak masyarakat yang sadar akan batasan-batasan tertentu dalam agama Islam mengenai jenis transaksi apa saja yang diperbolehkan dan diharamkan menurut syariat Islam. Sehingga, dengan hasil penelitian ini nantinya diharapkan masyarakat muslim dapat memilih lahan untuk investasi yang halal dan di dalamnya tidak mengandung unsur-unsur yang diharamkan.

Berikut pada Tabel 1 disajikan data perkembangan kapitalisasi dan indeks saham syariah yang tergabung dalam Jakarta Islamic Index.

Tabel 1. Indeks saham syariah

\begin{tabular}{ccc}
\hline Tahun & Indeks JII & Kapitalisasi \\
\hline 2012 & 594.789 & $1.671,00$ \\
2013 & 585.110 & $1.672,10$ \\
2014 & 691.039 & $1.944,53$ \\
2015 & 603.395 & $1.737,29$ \\
2016 & 694.127 & $2.035,30$ \\
\hline
\end{tabular}


Tabel 1. menjelaskan bahwa keberadaan saham syariah sangat diminati oleh para investor, hal itu tergambar dari semakin meningkatnya indeks saham syariah JII meskipun di tahun 2013 dan 2015 mengalami penurunan akan tetapi di tahun 2016 indeks saham kembali mengalami peningkatan. Selain itu, perkembangan indeks saham syariah dalam kelompok Jakarta Islamic Index (JII) menunjukkan nilai yang terus naik dari tahun ke tahun. Jika dibandingkan dengan tahun 2012, nilai kapitalisasi saham syariah di JII tercatat sebesar $1.671,00$ triliun rupiah. Selanjutnya mengalami peningkatan pada tahun berikutnya. Pada tahun 2015 jumlah kapitalisasi JII turun menjadi $1.737,29$ triliun atau sebesar $10,66 \%$ dari tahun sebelumnya namun langsung meningkat sebesar 298,01 triliun atau sebesar $17,15 \%$ di tahun 2016 yaitu sebesar 2.035,30 triliun.

Pengukuran kinerja keuangan perusahaan merupakan salah satu indikator yang dipergunakan oleh investor untuk menilai suatu perusahaan yang terekspresikan dalam harga pasar saham di bursa efek. Semakin baik kinerja keuangan perusahaan maka semakin tinggi pula return yang akan di dapatkan oleh investor. Investor akan berusaha mencari perusahaan yang memiliki kinerja yang terbaik dan menanamkan modalnya pada perusahaan tersebut dengan jalan membeli sahamsahamnya, dalam proses penilaian kinerja manajemen perusahaan, salah satu kriteria penting yang digunakan adalah ukuran kinerja keuangan perusahaan. Ukuran kinerja tersebut terdiri dari berbagai macam rasio seperti rasio likuiditas, rasio profitabilitas, dan rasio solvabilitas (Santoso, 2016). Dalam penelitian ini, kinerja keuangan diukur dengan rasio likuiditas $\left(\mathrm{X}_{1}\right)$, rasio profitabilitas $\left(\mathrm{X}_{2}\right)$, dan rasio solvabilitas $\left(\mathrm{X}_{3}\right)$. Di mana, dari ketiga rasio tersebut akan diteliti apakah memiliki pengaruh terhadap nilai perusahaan $(\mathrm{Y})$.

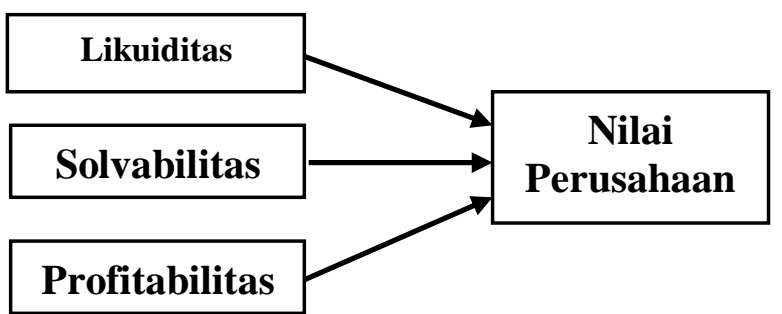

Gambar 1. Kerangka Konseptual

\section{METODE}

Penelitian ini menggunakan pendekatan kuantitatif. Menurut eksplanasinya penelitian ini termasuk penelitian asosatif. Penelitian dilakukan dengan pengambilan data sekunder dan hasil publikasi laporan keuangan perusahaan yang terdaftar pada Jakarta Islamic Index melalui situs www.idx.co.id. Pengambilan data dilakukan pada tahun 2012 sampai dengan tahun 2017. Penelitian ini bertujuan untuk menganalisis pengaruh kinerja keuangan yang diproksikan dengan 3 (tiga) variabel bebas, yaitu rasio likuiditas (quick ratio) sebagai X1, rasio profitabilitas (ROA) sebagai X2, dan rasio solvabilitas (Debt to Tatal Assets Ratio) sebagai X3 terhadap variabel dependen/terikat yang berupa nilai perusahaan (Price Book Value) sebagai Y pada perusahaaan yang terdaftar di Jakarta Islamic Index (JII). Teknik analisis data yang digunakan dalam penelitian ini adalah menggunakan regresi data panel. Model dasar yang digunakan pada penelitian ini adalah sebagai berikut:

NILAIit $=$ a + B1LKDit + B2PROFITit +
B3SOLit + eit $\ldots \ldots \ldots \ldots \ldots \ldots \ldots \ldots \ldots \ldots \ldots \ldots \ldots \ldots \ldots \ldots \ldots \ldots$

Pada regresi data panel terdapat empat model yang dapat digunakan. Model tersebut antara lain: model OLS pooled, model fixed effects least square dummy variabel (LSDV), model fixed effects withingroup dan model random effect (Gujarati: 2013). Pemilihan model yang akan dipakai, diseleksi dengan uji spesifikasi model. 


\section{HASIL DAN PEMBAHASAN}

Pertama-tama data panel diesmitasi menggunakan efek spesifikasi fixed. Uji yang dilakukan yaitu uji Chow. Uji ini bertujuan untuk mengetahui apakah sebaiknya model menggunaka fixed effect atau common effect.

$\mathrm{H}_{\mathrm{o}}$ : Common Effect; $\mathrm{H}_{\mathrm{a}}$ : Fixed Effect. Apabila hasil probabilitas chi-square kurang dari 5\%, maka ditolak. Sehingga, Model menggunakan fixed effect. Hasil dari estimasi menggunakan efek spesifikasi fixed adalah sebagai berikut:

Tabel 2. Rebundant Fixed Effect-Likelihood Ratio

\begin{tabular}{lcrc}
\hline Effects Test & Statistic & d.f. & Prob. \\
\hline $\begin{array}{l}\text { Cross- } \\
\text { section F }\end{array}$ & 1.415999 & $(13,67)$ & 0.0154 \\
$\begin{array}{l}\text { Cross- } \\
\text { section Chi- } \\
\text { square }\end{array}$ & 20.390754 & 13 & 0.0059 \\
\hline
\end{tabular}

Hasil tabel 2, diketahui probabilitas Chi-square sebesar 0,0059 sehingga menyebabkan $\mathrm{H}_{\mathrm{o}}$ ditolak. Maka model fixed adalah model yang sebaiknya digunakan. Untuk mengetahui apakah model random effect lebih baik dari fixed effect, dengan megnggunakan Correlated Random EffectHausmann Test, dengan kriteria apabila hasil probabilitas chi-square lebih dari 5\%, maka sebaiknya model menggunakan random effect. Hasil dari estimasi menggunakan efek spesifikasi random adalah sebagai berikut :

Tabel 3. Hasil uji Hausman

\begin{tabular}{lccc}
\hline $\begin{array}{l}\text { Test } \\
\text { Summary }\end{array}$ & $\begin{array}{r}\text { Chi-Sq. } \\
\text { Statistic }\end{array}$ & $\begin{array}{c}\text { Chi- } \\
\text { Sq. } \\
\text { d.f. }\end{array}$ & Prob. \\
\hline $\begin{array}{l}\text { Cross-section } \\
\text { random }\end{array}$ & 7.711683 & 3 & 0.0524 \\
\hline
\end{tabular}

Hasil probabilitas chi-square sebesar 0,0524. Sehingga dapat disimpulkan bahwa $\mathrm{H}_{\mathrm{o}}$ diterima dan sebaiknya menggunakan random effect.

Hasil uji spesifikasi pada Tabel 2 dan 3 sebaiknya model menggunakan estimasi dengan efek random effec). Pada pengujian sebelumnya, model telah lolos dari uji asumsi klasik, sehingga hasil estimasi konsisten dan tidak bias. Hasil estimasi model regresi data panel adalah sebagai berikut:

Tabel 4. Regresi Data Panel Random Effect

\begin{tabular}{ccc}
\hline Variable & Coefficient & Std. Error \\
\hline C & -18.28313 & 2.891219 \\
LKDT? & 0.380854 & 0.690214 \\
PROFIT? & 93.89098 & 7.266687 \\
SOL? & 30.51287 & 4.909201 \\
\hline R-squared & 0.749776 & \\
Adjusted R-squared & 0.740393 & \\
F-statistic & 79.90464 & \\
Prob(F-statistic) & 0.000000 & \\
\hline
\end{tabular}

Tabel 4, dapat disimpulkan bahwa pada regresi model random effect variabel profitabilitas dan solvabilitas berpengaruh terhadap nilai perusahaan yang terdaftar pada Jakarta Islamic Index yang mana secara berturut-turut hasil probabilitas sebesar 0,0000 dan 0,0000. Sedangkan variabel likuiditas tidak berpengaruh terhadap nilai perusahaan yang terdaftar pada Jakarta Islamic Index dengan nilai perusahaan sebesar 0,5826 serta nilai ketidakseimbangan sebesar $74,03 \%$. Secara simultan antara kinerja keuangan yang diproksikan oleh variabel likuiditas, profitabilitas dan solvabilitas berpengaruh siginifikan terhadap nilai perusahaan yang terdaftar dalam Jakarta Islamic Index (JII). Hal ini dibuktikan dengan nilai probabilitas regresi model random effect yaitu 0,000000 lebih kecil dari taraf signifikansi $5 \%$ dan nilai $\mathrm{F}$ statistik yang lebih besar dari $\mathrm{F}$ tabelnya.

\section{Pembahasan}

Hasil penelitian ini diketahui bahwa variabel likuiditas tidak berpengaruh terhadap nilai perusahaan. Hasil penelitian ini sesuai dengan penelitian yang dilakukan oleh Firnanda \& Oetomo, (2016); Febrianti, 
(2012) dimana likuiditas tidak berpengaruh secara signifikan terhadap nilai perusahaan pada perusahaan retail home yang terdaftar di Bursa Efek Indonesia. Hasil penelitian Dj et al., (2012) yang juga menyatakan bahwa kinerja keuangan dengan proksi likuiditas berpengaruh positif tidak signifikan terhadap nilai perusahaan pada perusahaan manufaktur di Bursa Efek Indonesia. Kondisi likuiditas yang tidak berpengaruh terhadap nilai perusahaan dapat diinterpretasikan bahwa nilai aktiva lancar dengan perbandingan hutang jangka pendek tidak memberikan pengaruh positif dalam meningkatkan nilai perusahaan, walaupun rasio yang digunakan untuk mengukur likuiditas juga menunjukkan tingkat kemanan kreditor jangka pendek, atau kemampuan perusahaan dalam membayar hutang-hutang jangka pendek perusahaan tersebut. Likuiditas yang tinggi dapat menyebabkan dana-dana yang ada dalam perusahaan menganggur, sehingga investor akan melihat itu sebagai sinyal negatif karena perusahaan harus menanggung resiko berupa biaya modal.

Selanjutnya profitabilitas berpengaruh terhadap nilai perusahaan. Hasil tersebut dapat diinterpretasikan bahwa setiap terdapat kenaikaan $1 \%$ profitabilitas, maka akan menaikkan nilai perusahaan sebesar 93.89098. Hasil penelitian ini sesuai dengan penelitian yang dilakukan oleh Sucuahi \& Cambarihan, (2016); Sabrin et al., (2016); Andawasatya et al., (2017) yang menyatakan bahwa profitabilitas berpengaruh signifikan terhadap nilai perusahaan pada perusahaan di negara Filipina dan yang terda terdaftar di Bursa Efek Indonesia. Pengaruh tersebut disebabkan oleh kontribusi peningkatan laba atau peningkatan nilai rasio profitabilitas dapat memberikan sinyal atau indikasi bagi para pemegang saham bahwa tingkat pengembalian investasi semakin tinggi dan gambaran prospek perusahaan yang semakin baik karena adanya potensi peningkatan keuntungan atas jumlah modal yang telah disediakan oleh para pemegang saham.

Selain itu, ketika suatu perusahaan meningkatkan kinerja keuangannya, hal tersebut dapat menciptakan nilai perusahaan. Hasil penelitian tersebut menandakan bahwa memiliki nilai perusahaan yang baik akan menarik lebih banyak investor dan kepentingan pihak lain untuk ikut serta dan berperan bagi perusahaan. Sehingga, kinerja keuangan merupakan hal yang penting untuk mencitptakan dan menentukan nilai perusahaan guna terwujudnya investasi yang handal (Sucuahi \& Cambarihan, 2016), karena ketika tingkat keuntungan dalam kinerja keuangan yang dicapai oleh suatu perusahaan semakin baik, maka akan berpengaruh positif dalam meningkatkan nilai perusahaan.

Solvabilitas berpengaruh terhadap nilai perusahaan, hasil ini dapat diinterpretasikan bahwa setiap terdapat kenaikaan $1 \%$ solvabilitas, maka akan menaikkan nilai perusahaan sebesar 30.51287. Hasil penelitian ini sesuai dengan penelitian yang dilakukan oleh Santoso, (2016) yang menyatakan bahwa rasio solvabilitas berpengaruh secara signifikan terhadap nilai perusahaan. Hal ini diperkuat oleh penelitian yang dilakukan oleh (Susilaningrum, 2016); (Firnanda \& Oetomo, 2016) (Susilaningrum, 2016) yang menyatakan bahwa terdapat pengaruh rasio solvabilitas terhadap nilai perusahaan pada industri sektor pertambangan dan pada periode 2012-2014. Hasil yang sama juga diperoleh Firnanda dan Oetomo (2016) dimana solvabilitas berpengaruh signifikan terhadap nilai perusahaan pada perusahaan retail home yang terdaftar di Bursa Efek Indonesia.

Perusahaan yang semakin banyak melakukan hutang, dipandang sebagai perusahaan yang yakin dengan prospek perusahaan di masa yang akan datang. Perusahaan yang memiliki rasio solvabilitas 
yang tinggi, akan berdampak pada timbulnya resiko kerugian lebih besar, namun juga ada kesempatan untuk mendapat laba yang lebih besar. Investor menganggap perusahaan yang mempunyai banyak hutang akan mempunyai kesempatan dalam menggunakan modalnya untuk ekspansi atau pengembangan, dengan harapan semakin berkembangnya perusahaan maka keuntungan bagi perusahaan dan investor juga akan semakin naik sehingga investor tertarik untuk membeli saham perusahaan tersebut.

\section{SIMPULAN}

Nilai aktiva lancar dengan perbandingan hutang jangka pendek tidak memberikan pengaruh positif dalam meningkatkan nilai perusahaan, walaupun rasio yang digunakan untuk mengukur likuiditas juga menunjukkan tingkat kemanan kreditor jangka pendek, atau kemampuan perusahaan dalam membayar hutang-hutang jangka pendek perusahaan tersebut. Likuiditas yang tinggi dapat menyebabkan dana-dana yang ada dalam perusahaan menganggur, sehingga investor akan melihat itu sebagai sinyal negatif karena perusahaan harus menanggung resiko berupa biaya modal. Peningkatan nilai rasio profitabilitas dapat memberikan sinyal atau indikasi bagi para pemegang saham bahwa tingkat pengembalian investasi semakin tinggi dan gambaran prospek perusahaan yang semakin baik karena adanya potensi peningkatan keuntungan atas jumlah modal yang telah disediakan oleh para pemegang saham. Perusahaan yang semakin banyak melakukan hutang, dipandang sebagai perusahaan yang yakin dengan prospek perusahaan di masa yang akan datang. Perusahaan yang memiliki rasio solvabilitas yang tinggi, akan berdampak pada timbulnya resiko kerugian lebih besar, namun juga ada kesempatan untuk mendapat laba yang lebih besar.

\section{REFERENSI}

Aggarwal, D., \& Padhan, P. C. (2017). Impact of Capital Structure on Firm Value: Evidence from Indian Hospitality Industry. Theoretical Economics Letters, 7, 9821000.

https://doi.org/10.4236/tel.2017.74067

Andawasatya, R., Indrawati, N. K., \& Aisjah, S. (2017). The Effect of Growth Opportunity, Profitability, Firm Size to Firm Value through Capital Structure (Study at Manufacturing Companies Listed On the Indonesian Stock Exchange). Imperial Journal of Interdisciplinary Research (IJIR), 3(2), 1887-1894.

Cheung, W. M., Chung, R., \& Fung, S. (2015). The effects of stock liquidity on firm value and corporate governance: Endogeneity and the REIT experiment. Journal of Corporate Finance, 35, 211-231. https://doi.org/10.1016/j.jcorpfin.2015.09.0 01

Dj, A. M., Artini, L. G. S., \& Suarjaya, A. . G. (2012). Pengaruh Kinerja Keuangan Terhadap Nilai Perusahaan Pada Perusahaan Manufaktur Di Bursa Efek Indonesia. Jurnal Manajemen, Strategi Bisnis, Dan Kewirausahaan, 6(2), 130138.

Erlina, N. (2018). Pengaruh Likuiditas, Solvabilitas, Prfotabilitas terhadap NIlai Perusahaan Pertambangan di Bursa Efek Indonesia. Jurnal Manajemen Kompeten, 1(1), 13-28.

Fang, V. W., Noe, T. H., \& Tice, S. (2009). Stock market liquidity and firm value. Journal of Financial Economics, 94(1), 150-169.

https://doi.org/10.1016/j.jfineco.2008.08.0 07

Febrianti, M. (2012). Faktor-Faktor Yang Mempengaruhi Nilai Perusahaan Pada Industri Pertambangan Di Bursa Efek Indonesia. Jurnas Bisnis Dan Akuntansi, 14(2), 141-156.

Firnanda, T., \& Oetomo, H. W. (2016). Analisis likuiditas, profitabilitas, solvabilitas, dan perputaran persediaan terhadap nilai perusahaan. Jurnal Ilmu Dan Riset Manajemen, 5(2), 1-15.

Mangantar, M., \& Ali, M. (2015). An Analysis 


\section{JURNAL ILMIAH MANAJEMEN DAN BISNIS ISSN 1693-7619 (print) | ISSN 2580-4170 (online), http://jurnal.umsu.ac.id/index.php/mbisnis}

of the Influence of Ownership Structure, Investment, Liquidity and Risk to Firm Value: Evidence from Indonesia. American Journal of Economics and Business Administration, $\quad 7(4), \quad$ 166-176. https://doi.org/10.3844/ajebasp.2015.166.1 76

Meythi. (2013). Rasio keuangan terbaik untuk memprediksi nilai perusahaan. Jurnal Keuangan Dan Perbankan, 17(2), 200210.

Prajanto, A., \& Pratiwi, R. D. (2017). Analisis Nilai Perusahaan Manufaktur di Indonesia dari Perspektif Kinerja Keuangan. Jurnal Akuntansi Indonesia, 6(1), 13-28.

Sabrin, Sarita, B., Takdir, D., \& Sujono. (2016). The Effect of Profitability on Firm Value in Manufacturing Company at Indonesia Stock Exchange. The International Journal Of Engineering And Science (IJES), 5(10), 81-89.

Santoso, B. H. (2016). Pengaruh Kinerja Keuangan Terhadap Nilai Perusahaan Pada Perusahaan Jasa Telekomunikasi. Jurnal Ilmu Dan Riset Manajemen, 5(2), 1-21.

Sidhu, M. K. (2012). Stock Market Liquidity and Firm Value- Indian Evidences. IOSR Journal of Business and Management, 5459.

Simamora, H. (2010). Keputusan Akuntansi Basis Pengambilan Bisnis. Jakarta: Salemba Empat.

Sucuahi, W., \& Cambarihan, J. M. (2016). Influence of Profitability to the Firm Value of Diversified Companies in the Philippines. Accounting and Finance Research, 5(2), 149-153. https://doi.org/10.5430/afr.v5n2p149

Susilaningrum, C. (2016). . Pengaruh Return On Assets, Rasio Likuiditas, Dan Rasio Solvabilitas Terhadap Nilai Perusahaan Dengan Pengungkapan Corporate Social Responsibility (CSR) Sebagai Variabel Moderasi. Jurnal Profita, 4(8), 1-17.

Wang, Y. J. (2002). Liquidity management, operating performance, and corporate value: evidence from Japan and Taiwan. Journal of Multinational Financial Management, 12(2), 159-169. 